\title{
Focus on TGF- $\beta$ Signalling
}

\section{TGF- $\beta$ superfamily expression and actions in the endometrium and placenta}

\author{
Rebecca L Jones ${ }^{1,2}$, Chelsea Stoikos ${ }^{1}$, Jock K Findlay ${ }^{1}$ and Lois A Salamonsen ${ }^{1}$ \\ ${ }^{1}$ Prince Henry's Institute of Medical Research, PO Box 5152, Clayton, VIC 3166, Australia and ${ }^{2}$ Academic Unit of \\ Child Health, Division of Human Development, University of Manchester, St Mary's Hospital Research Floor, \\ Hathersage Road, Manchester, M13 OJH, UK
}

Correspondence should be addressed to $R$ L Jones; Email: rebecca.lee.jones@manchester.ac.uk

\begin{abstract}
Transforming growth factor $\beta$ (TGF $\beta$ ) superfamily members are closely associated with tissue remodelling events and reproductive processes. This review summarises the current state of knowledge regarding the expression and actions of TGF $\beta$ superfamily members in the uterus, during the menstrual cycle and establishment of pregnancy. TGF $\beta$ s and activin $\beta$ subunits are abundantly expressed in the endometrium, where roles in preparation events for implantation have been delineated, particularly in promoting decidualisation of endometrial stroma. These growth factors are also expressed by epithelial glands and secreted into uterine fluid, where interactions with preimplantation embryos are anticipated. Knockout models and embryo culture experiments implicate activins, TGF $\beta$, nodal and bone morphogenetic proteins (BMPs) in promoting pre- and post-implantation embryo development. TGF $\beta$ superfamily members may therefore be important in the maternal support of embryo development. Following implantation, invasion of the decidua by fetal trophoblasts is tightly modulated. Activin promotes, whilst TGF $\beta$ and macrophage inhibitory cytokine-1 (MIC-1) inhibit, trophoblast migration in vitro, suggesting the relative balance of TGF $\beta$ superfamily members participate in modulating the extent of decidual invasion. Activins and TGF $\beta$ s have similar opposing actions in regulating placental hormone production. Inhibins and activins are produced by the placenta throughout pregnancy, and have explored as a potential markers in maternal serum for pregnancy and placental pathologies, including miscarriage, Down's syndrome and pre-eclampsia. Finally, additional roles in immunomodulation at the materno-fetal interface, and in endometrial inflammatory events associated with menstruation and repair, are discussed.

Reproduction (2006) 132 217-232
\end{abstract}

\section{Introduction}

Reproductive organs are unusual in their recurrent proliferative and remodelling activity in adult life. In particular, the human endometrium undergoes remarkable cycles of remodelling, involving proliferation, differentiation, breakdown and repair, every 28 days. This cyclical activity is regulated by the ovarian steroids oestrogen and progesterone, but at a paracrine level by a myriad of growth factors, cytokines and proteases. Unsurprisingly, transforming growth factor (TGF) $\beta$ superfamily members are abundantly and dynamically expressed in the endometrium, and appear, through their actions associated with cell proliferation, differentiation, apoptosis and tissue remodelling, to have instrumental roles in modulating cellular events involved in menstruation, proliferation, decidualisation and the establishment of pregnancy. Further, the expression of many TGF $\beta$ superfamily members have been described in the placenta, another organ undergoing rapid development and remodelling. This review will focus on the expression, production and roles of TGF $\beta$ and activins/inhibins in the human endometrium and placenta, and introduce the emerging roles of these and other family members in modulating the events during the preparation for, and establishment of, pregnancy.

\section{Overview of endometrial function}

The endometrium is a highly specialised tissue, providing an optimal environment to enable, yet regulate, the implantation of the semi-allogeneic 
embryo. Following oestrogen-induced proliferation, progesterone induces differentiative events within all compartments of the endometrium, creating an environment receptive for blastocyst attachment and invasion (Salamonsen \& Jones 2003). Endometrial epithelial glands undergo morphological and functional differentiation, and commence active secretion of a complex nutritive and growth factor-rich media contributing to uterine fluid. This provides support to the pre-implantation embryo, promoting growth and development before endometrial attachment. In some primates, rodents and bats, stromal fibroblasts surrounding the developing spiral arterioles begin to differentiate, or decidualise, eventually producing the decidua of pregnancy. Cells enlarge, become more rounded, and deposit a decidual-specific extracellular matrix (ECM), rich in laminin, collagen IV and fibronectin; they also start to produce a wide range of cytokines, growth factors and immunomodulatory agents that are undoubtedly involved in maternal regulation of trophoblast invasion. In addition, the decidua possesses a unique immune environment, characterised by the presence of large numbers of uterine-specific natural killer cells (uNK) and smaller population of macrophages (Bulmer et al. 1988, King et al. 1998). These appear to be recruited and acquire their uterine-specific phenotype by chemokines and cytokines (particularly interleukin-15) produced by the decidua (Verma et al. 2000, Croy et al. 2003). The specific exclusion of inflammatory and cytotoxic lymphocytes, together with the defined interactions between uNKs and foetal trophoblasts (via human leukocyte antigen; HLA-G), combine to create an environment permissive to embryo implantation (King et al. 2000).

In the absence of pregnancy in women and old world monkeys, the endometrium functionalis is shed during menstruation. The occurrence of menstruation is thought to be an evolutionary adaptation related to the highly invasive nature of trophoblast invasion in these species. Significant endometrial preparation (decidualisation, spiral arteriole development, etc.) occurs in anticipation of pregnancy, producing a terminally differentiated endometrium that must be shed ahead of a subsequent new ovulatory cycle. Progesterone withdrawal, due to regression of the corpus luteum, lifts the repressive antiinflammatory effect of this pregnancy-related steroid hormone, leading to a cascade of events resulting in inflammatory cell influx, production of inflammatory cytokines, prostaglandins, vasomodulatory agents and proteases, and culminating in endometrial breakdown. These events are very focal, occurring simultaneously with endometrial repair, reinforcing the involvement of infiltrating leukocytes and their locally secreted factors in the initiation of endometrial breakdown. Endometrial repair occurs very rapidly, with re-epithelisation complete within $48 \mathrm{~h}$ of the initiation of menstrual bleeding (Ferenczy 1976). Importantly, endometrial repair occurs without scarring, similar to foetal repair in utero (Samuels \& Tan 1999); however, the mechanisms are poorly understood.

\section{Regulation of endometrial function}

Many members of the TGF $\beta$ superfamily are expressed by human endometrium at different stages of the menstrual cycle, consistent with their general involvement in rapidly proliferating or remodelling tissues. The three TGF $\beta$ isoforms are differentially expressed in endometrium, with TGF $\beta 2$ predominantly localising to stroma whilst TGF $\beta 1$ and TGF $\beta 3$ are present in both epithelial and stromal cells (Gold et al. 1994, Godkin \& Dore 1998). TGF $\beta 1$ has been shown to be secreted apically from endometrial glands and is present in uterine fluid (Polli et al. 1996). Cyclical changes in expression level are not evident for TGF $\beta 1$ and TGF $\beta 2$, whilst maximal glandular production of TGF $\beta 3$ occurs in the late secretory phase. Activins are also highly abundant in the endometrium. Activin $\beta$ subunits ( $\beta A$ and $\beta B$ ) are primarily localised to endometrial glands in the non-pregnant endometrium (Leung et al. 1998, Otani et al. 1998, Petraglia et al. 1998, Jones et al. 2000), with maximal levels seen in the secretory phase. Expression of inhibin $\alpha$ subunit has been described, again in glandular epithelium, but to a lesser degree than activin $\beta$ subunits, indicating that activin dimers are preferentially produced. Indeed, isolated epithelial cells in culture secrete activin A at 1000-fold higher concentrations than either inhibin A or B; similarly, activin $A$ is secreted from epithelial glands in vivo into uterine fluid (Petraglia et al. 1998).

The production and secretion of TGF $\beta$ and activins by epithelial glands in the secretory phase suggest roles in either the preparation of the endometrium for implantation, or direct actions on the pre-implantation embryo, facilitating development or differentiation for implantation. In support of the first theory, TGF $\beta$ receptors are expressed by oviductal/Fallopian tube and uterine epithelial cells (Zhao et al. 1994, Chow et al. 2001). Recently, it has been demonstrated that both TGF $\beta 1$ and activin A enhance the production of the pro-implantatory cytokine, leukaemia inhibitory factor from endometrial epithelial cells (Perrier d'Hauterive et al. 2005) (Fig. 1). Furthermore, retroviral overexpression of the TGF $\beta$ antagonist, lefty, in the mouse uterus in the periimplantation phase reduces the number of implantation sites, possibly by negatively influencing the endometrial environment (Tang et al. 2005a). This is reinforced by its abnormally elevated expression in human endometrium during the receptive phase in women experiencing infertility (Tang et al. 2005a).

\section{Regulation of decidualisation}

Endometrial decidualisation induces the production of a wide array of growth factors and cytokines, which act in 


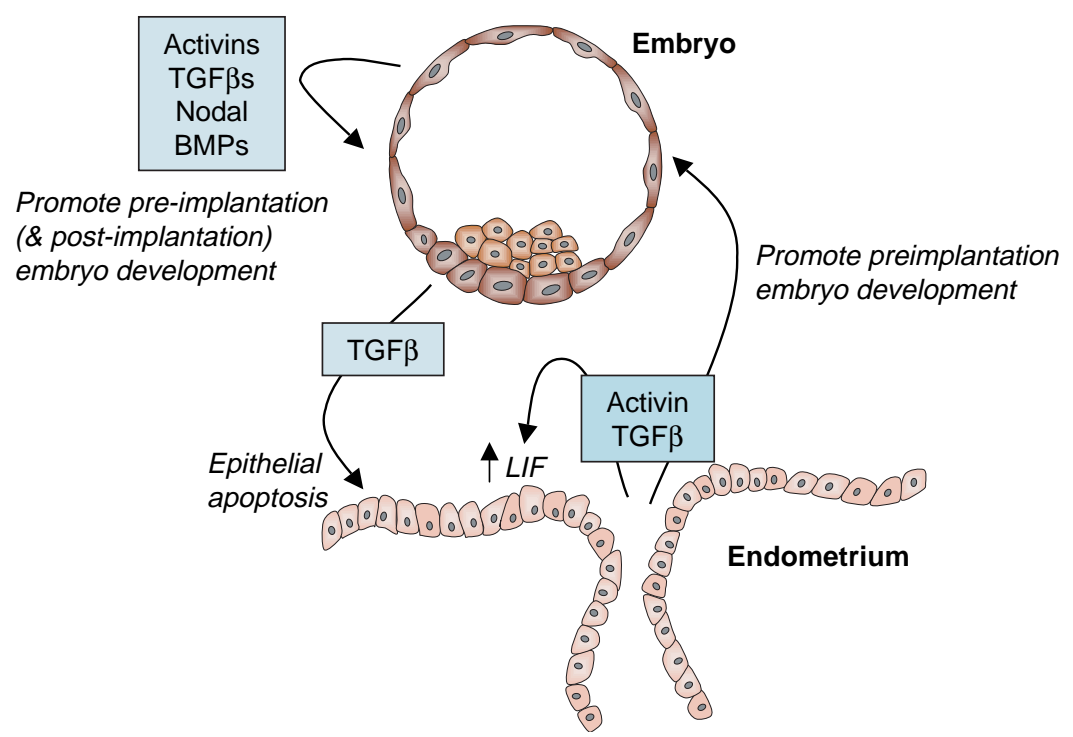

Figure 1 Summary of the proposed actions of transforming growth factor (TGF) $\beta$ superfamily members during implantation. Activins and TGF $\beta$ s are produced and secreted by the epithelial lining of the Fallopian tube and uterus. Whilst autocrine actions of activins and TGF $\beta$ s on the uterus have been described during the preparation for implantation (such as the stimulation of pro-implantatory leukaemia inhibitor factor production), receptors for these factors are also expressed by embryos at varying stages of development. Indeed, in vitro studies have demonstrated that activin A and TGF $\beta$ promote pre-implantation embryo development suggesting these factors are involved in maternal-foetal communication during the establishment of pregnancy. Continued functions can be extrapolated for these factors in post-implantation development from the spatial and temporal expression patterns of the ligands, receptors and binding proteins. TGF $\beta$ secreted from the blastocyst has been proposed to induce apoptosis of endometrial epithelial cells during implantation.

concert to mediate the decidualisation reaction, and/or to create an extracellular and immunological environment conducive to trophoblast invasion. Activin $\beta A$ and $\beta B$ subunits are dramatically upregulated during decidualisation (Otani et al. 1998, Jones et al. 2000) both in in vivo and in vitro models of decidualisation. Similarly, TGF $\beta$ isoforms are present to varying extents in the decidua (particularly TGF $\beta 2$ ) (Simpson et al. 2002), and both TGF $\beta$ and activins are highly expressed in the extensively decidualised endometrium induced by intrauterine delivery of progestin (Jones et al. 2000, Roopa et al. 2003). Furthermore, activin A promotes decidualisation in vitro, while neutralisation of activin action by treatment with follistatin significantly retards the decidual response (Jones et al. 2002a, Tierney \& Giudice 2004) (Fig. 2). This appears to be due, at least in part, to the stimulation of matrix metalloproteinases (MMPs) by activin in endometrial cells (Jones et al. 2006). In our in vitro model of decidualisation, we show that MMP-2 secretion is enhanced when decidualisation is accelerated by treatment with activin, whilst its production is ablated by blockade of activin bioactivity by inhibin $\mathrm{A}$, coincident with reduced decidualisation. As MMP activity is critical for decidualisation in the rat and primate, for endometrial remodelling and growth factor processing (Alexander et al. 1996, Rechtman et al. 1999, Strakova et al. 2003), this provides a probable downstream mechanism for activin during decidualisation. Whether TGF $\beta$ s influence decidualisation is unclear, as studies in the literature report contrasting effects on prolactin production (an established marker of decidualisation) by endometrial stroma (Kubota et al. 1997, Kim et al. 2006). Other TGF $\beta$ superfamily members are likely to be expressed by the decidua, and involved in decidualisation. For example, macrophage inhibitory cytokine (MIC)- 1 is upregulated in decidual cells and facilitates decidualisation in vitro (Marjono et al. 2003). However, its mode of action differs from that of activin, as in this model MIC- 1 inhibits activation of MMP-2 and -9 (Fig. 2).

In the rodent uterus, activin is similarly upregulated with the onset of decidualisation, yet its expression is dynamic, and follows a characteristic wave-like pattern of up- and downregulation preceding the wave of decidualisation (Gu et al. 1995, Jones and colleagues unpublished observations). With blastocyst attachment, activin $\beta A$ expression becomes polarised to the primary decidual zone. In the following days, activin expression switches from anti-mesometrial to mesometrial zones with the initiation of secondary decidualisation, but by mid-pregnancy, expression is limited to the decidua basalis. These expression patterns suggest a role for activins in preparation of the endometrium for decidualisation, potentially through regulation of MMP expression, which follow a similar pattern (Alexander et al. 1996), or through stimulation of decidual-specific ECM components (e.g. fibronectin) (Caniggia et al. 1997a). TGF $\beta 1$ and TGF $\beta 2$, but not TGF $\beta 3$, are predominantly expressed by stroma immediately underlying the luminal and glandular epithelium in the rat, and 


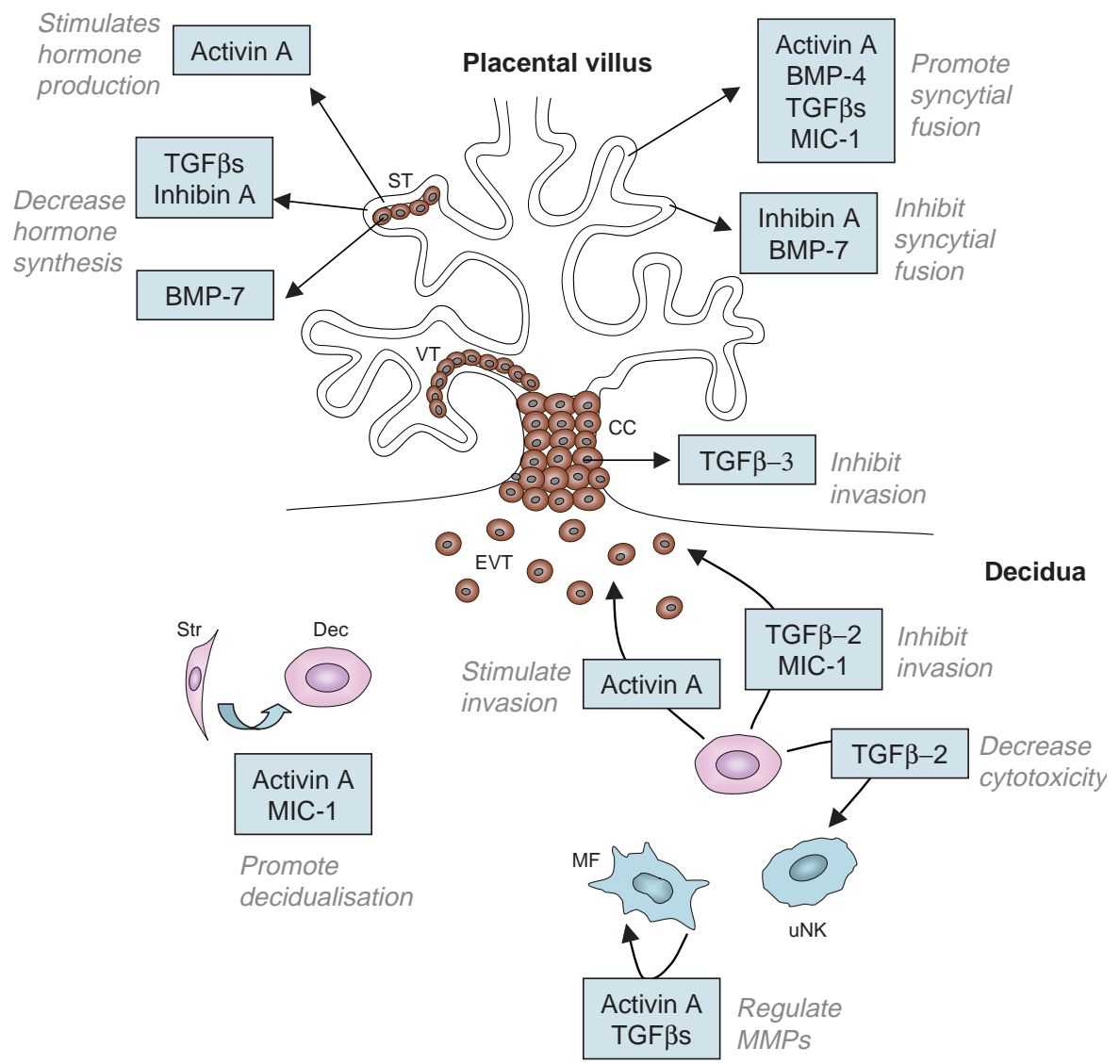

Figure 2 Summary of the proposed actions of TGF $\beta$ superfamily members at the maternal-foetal interface during establishment of pregnancy. A number of TGF $\beta$ superfamily ligands are expressed by the placental villous, by the either syncytiotrophoblast (ST) or inner villous cytotrophoblast layer (VT). These have been shown to modulate hormone production (oestrogen, progesterone, placental lactogen), and/or syncytial fusion (as assessed by human chorionic gonadotrophin production). Activin A and macrophage inhibitory cytokine (MIC-1) are also expressed by the maternal decidua, and promote the differentiation of stromal cells (Str) into decidualised cells (Dec). The two growth factors, together with transforming growth factor (TGF) $\beta 2$, play important roles in the decidual regulation of extravillous cytotrophoblast (EVT) invasion, whilst differentiating cytotrophoblast cells in the cell column (CC) also produce TGF $\beta 3$ which is inhibitory to invasion. Decidual TGF $\beta$ is proposed to act on uterine natural killer cells to downregulate their cytotoxicity producing the uterine-specific phenotype. Tissue macrophages $(M \Phi)$ within the implantation site, and in the non-pregnant endometrium, produce a wide range of cytokines, including TGF $\beta$ and activins, which have opposing actions to tightly regulate matrix metalloproteinase expression and activity.

are upregulated following implantation at day 5-6 of pregnancy (Shooner et al. 2005). Later in pregnancy, both TGF $\beta$ (all isoforms) and activin $A$ have been attributed with roles in apoptotic regression of the decidua basalis in the rat, both through their overlapping localisation with apoptotic cells and their pro-apoptotic actions on decidual cells in vitro (Moulton 1994, Tessier et al. 2003, Shooner et al. 2005). Undoubtedly, these actions are tightly regulated in both rodent and human; antagonists of TGF $\beta$ and activins, lefty $A$ and follistatin respectively, are expressed in the decidua, generally fluctuating in conjunction with their 'ligands' (Jones et al. 2002b, Tessier et al. 2003, Tang et al. 2005b). Expression and activation of Smads 2 and 4 also correlate with activin expression during the establishment of pregnancy, and later with TGF and activin during decidual regression (Liu et al. 2004).
Bone morphogenetic proteins (BMPs) have been detected in the murine uterus during decidualisation and the establishment of pregnancy. In particular, the spatial and temporal expressions of BMP-2 tightly mimics the spread of the decidualisation reaction (Ying \& Zhao 2000, Paria et al. 2001). Its mRNA is immediately upregulated in the anti-mesometrial stroma underlying the implantating blastocyst, where it appears to be an early event during primary decidualisation. Indeed, the application of embryonic factor heparin binding-epidermal growth factor (EGF) to the uterine epithelium, via coated glass beads, stimulates the expression of stromal BMP-2 (Paria et al. 2001). Expression shifts to the secondary decidual zone with the progression of normal pregnancy. Other BMPs are present, but exhibit distinct expression patterns: BMP-7 is expressed throughout the stroma in advance of 
implantation, and subsequently becomes highly localised to the subepithelial stroma in the mesometrial zone; BMP-8a is upregulated in the anti-mesometrial zone after primary decidual regression; and BMP-4 is predominantly associated with decidual vasculature (Ying \& Zhao 2000). In addition, a number of BMP-binding proteins (noggin, twisted gastrulation and dan/dante) and co-receptors (Dragon) have been detected in the implantation site (Paria et al. 2001), further supporting important roles for the BMP family in modulating endometrial function. Although the functions of the BMPs in the decidua have not been established, two separate studies indicate roles for BMP-2 and -5 in regulating embryo spacing during implantation (Pfendler et al. 2000, Paria et al. 2001). To date, there are no reports describing the expression of BMPs by human uterine cells.

\section{Regulation of early embryo development}

Pre-implantation embryos express receptors for activin (ActRs) and TGF $\beta$ (TGF $\beta R$ ) and hence would be responsive to growth factors secreted by the endometrium. ActRs are expressed by human pre-implantation embryos and are upregulated at the blastocyst stage ( $\mathrm{He}$ et al. 1999). In the mouse, the differential expression of type II receptors has been identified, with ActRIIA limited to the trophectoderm (TE), and ActRIIB present in both inner cell mass (ICM) and TE cells (Debieve et al. 2006). Maternally derived TGF $\beta R I$ and TGF $\beta R I I$ mRNA transcripts are detectable in oocytes and one cell embryos (Osterlund \& Fried 2000). With the activation of embryonic genome, TGF $\beta R$ I is upregulated, whilst TGF $\beta$ RII mRNA is only detectable at the blastocyst stage (Roelen et al. 1998, Chow et al. 2001), where the protein becomes limited to the TE. Interestingly, oocyte-derived TGF $\beta R$ II appears to be critical for embryonic development, as interfering with signalling through this receptor during in vitro embryo maturation leads to a block in development at the two-cell stage (Roelen et al. 1998). Both mRNA and protein for Smads 2 and 3 are present in human embryos throughout pre-implantation development (Osterlund \& Fried 2000), demonstrating that all elements of the signalling pathways for activin and TGF $\beta$ are present. Co-expression of inhibitory Smad 7 indicates the potential for tight regulation of activin/ TGF $\beta$ action during cleavage and blastocyst development (Zwijsen et al. 2000).

Exogenous TGF $\beta$ facilitates embryonic development in vitro, promoting blastocyst proliferation and development and increasing blastocyst cell number (Paria \& Dey 1990, Lim et al. 1993, Nowak et al. 1999) (Fig. 1). Activin A has similar actions: treatment of cultured rodent or bovine embryos with recombinant activin A promotes embryo development, by increasing blastocyst cell number, reducing time taken to reach blastocyst stage and improving hatching rates (Orimo et al. 1996, Yoshioka et al. 1998, Mtango et al. 2003). In addition, activin A treatment of rat blastocysts in vitro induces apoptosis, suggesting a role for activin in physiological apoptosis of blastomeres during embryo development (Debieve et al. 2006). Pre-implantation embryos also express activin subunits and TGF $\beta$ : in both mouse and human embryos activin $\beta A$ and $\beta B$ are maximally expressed at the blastocyst stage and become localised to the ICM (Albano et al. 1993, Lu et al. 1993, He et al. 1999), whilst TGF $\beta$ expression appears to peak between the eight cell stage and morula in both ICM and TE, and thereafter declines (Chow et al. 2001). Interestingly, TGF $\beta$ secreted by the blastocyst induces apoptosis of uterine epithelial cells, suggesting that it plays an important role in embryonic signalling to the endometrium during implantation (Kamijo et al. 1998). Many TGF $\beta$ superfamily members (e.g. activins, TGF $\beta$ s, nodal and BMPs), their receptors and Smads are expressed in later stage embryos, and have been attributed with modulatory roles during gastrulation and organogenesis (lannaccone et al. 1992, Winnier et al. 1995, Zhang \& Bradley 1996, Gu et al. 1998, Song et al. 1999, Zwijsen et al. 1999, Zwijsen et al. 2000). The phenotypes associated with gene knockout of TGF $\beta$ superfamily member ligands, receptors and Smads (including embryonic and perinatal lethality) are summarized in Table 1. The detailed description of embryonic-TGF $\beta$ superfamily members expression patterns and actions are outside the realms of this review.

\section{Placental development and function}

Placental development is equally dynamic. TE differentiation into invasive syncytial trophoblast is initiated upon attachment to the endometrial epithelium, and this trophoblast forms a protective layer surrounding the blastocyst. The inner lining of cytotrophoblast cells forms the trophoblast shell, from which columns of cytotrophoblast project, forming anchoring columns upon contact with the decidua. During the first few weeks of pregnancy, the villous structure of the placenta develops; villous projections lined with syncytiotrophoblast (ST) generated by fusion of villous cytotrophoblast cells, enclose foetal capillaries, and from the second trimester of pregnancy become the major route of gaseous and nutrient exchange between foetus and mother (Hamilton \& Boyd 1960). The ST is also the site of hormone synthesis, including progesterone and human chorionic gonadotrophin (hCG), critical for maintaining pregnancy. Maximal decidual invasion by trophoblast cells occurs between 5 and 12 weeks of pregnancy. Extravillous cytotrophoblast (EVT) cells differentiate from cytotrophoblast cells in the anchoring columns; contact with decidual-derived factors stimulates their differentiation and acquisition of invasive potential. EVTs invade the decidual stroma as interstitial (iEVTs), and 
Table 1 Overview of mouse knockout phenotypes for transforming growth factor (TGF) $\beta$ superfamily ligands, receptors and Smads. Genes have been classified according to the broad phenotype, with a brief description for genes of interest (in bold). Modified from Chang et al. (2002).

\begin{tabular}{|c|c|c|}
\hline Outcome of gene knockout & Gene ablated & References \\
\hline \multicolumn{3}{|l|}{ Reproductive abnormalities } \\
\hline \multirow[t]{6}{*}{ Ligands } & $\begin{array}{l}\text { Inhibin } \alpha \text { : elevated FSH and activin levels, gonadal } \\
\text { stromal tumours, cachexia and death prior to repro- } \\
\text { ductive maturity }\end{array}$ & Matzuk et al. (1992) \\
\hline & $\begin{array}{l}\text { Activin } \beta \text { B: elevated activin } \beta A \text { expression, increased } \\
\text { gestation length, perinatal lethality of offspring }\end{array}$ & Vassalli et al. (1994) \\
\hline & $\begin{array}{l}\text { BMP-8B: male infertility due to germ cell depletion; } \\
\text { defects in PGC and allantois development }\end{array}$ & Ying et al. (2000) \\
\hline & $\begin{array}{l}\text { BMP-15: female subfertility; impaired ovulation, } \\
\text { cumulus cell expansion and fertilisation }\end{array}$ & Yan et al. (2001) \\
\hline & $\begin{array}{l}\text { GDF-9: female infertility; folliculogenesis arrested at } \\
\text { primary follicle stage }\end{array}$ & Dong et al. (1996) \\
\hline & $\begin{array}{l}\text { MIS: females fertile but experience early recruitment } \\
\text { and depletion of primordial follicles, males develop } \\
\text { uteri }\end{array}$ & Behringer et al. (1994), Durlinger et al. (2001) \\
\hline \multirow[t]{2}{*}{ Receptors } & $\begin{array}{l}\text { ActRII: female infertility, thin uteri and small ovaries, } \\
\text { normal folliculogenesis, but no ovulation }\end{array}$ & Matzuk et al. (1995b) \\
\hline & $\begin{array}{l}\text { ALK6: female infertility due to defects in oestrous cycle } \\
\text { regularity, cumulus cell expansion, oestradiol biosyn- } \\
\text { thesis and endometrial gland formation }\end{array}$ & Yi et al. (2001) \\
\hline Smads & $\begin{array}{l}\text { Smad 3: reduction in body size; reduced litter size } \\
\text { from homozygous matings }\end{array}$ & Zhu et al. (1998) \\
\hline \multicolumn{3}{|c|}{ 11011 } \\
\hline Ligands & $\begin{array}{l}\text { Activin } \beta \text { B knockin (BK): } \beta \text { B gene knocked into } \beta \text { A } \\
\text { locus, rescues neonatal lethality of } \beta \text { A knockout, } \\
\text { decreased fertility due to reduced preovulatory } \\
\text { follicles. Activin } \beta C \text {, Activin } \beta E \text {, BMP-3, BMP-5, } \\
\text { BMP-6, BMP-8A, GDF-5, GDF-7, GDF-8, GDF-10, } \\
\text { GDF-11/BMP-11, GDF-15 }\end{array}$ & $\begin{array}{l}\text { Storm et al. (1994), McPherron et al. (1997, 1999), } \\
\text { Solloway et al. (1998), Zhao et al. (1998, 1999), } \\
\text { Solloway \& Robertson (1999), Brown et al. (2000), } \\
\text { Lau et al. (2000), Hsiao et al. (2000), Daluiski et al. } \\
\text { (2001), Settle et al. (2001) }\end{array}$ \\
\hline Receptors & ALK 7 & (Jornvall et al. 2004) \\
\hline \multicolumn{3}{|l|}{ Embryonic lethal } \\
\hline \multirow[t]{3}{*}{ Ligands } & BMP-2: abnormal amniochorion development & Zhang \& Bradley (1996) \\
\hline & $\begin{array}{l}\text { Nodal: abnormal placentation due to increased } \\
\text { numbers of invasive giant cells }\end{array}$ & lannaccone et al. (1992), Conlon et al. (1994) \\
\hline & BMP-4, GDF-1, lefty-1, lefty-2 & $\begin{array}{l}\text { Winnier et al. (1995), Meno et al. (1998, 1999), and } \\
\text { Rankin et al. (2000) }\end{array}$ \\
\hline Receptors & $\begin{array}{l}\text { ALK-1, ALK-2, ALK-3, ALK-4, ALK-5, BMPR-2, } \\
\beta \text {-glycan (TGF } \beta \text { RIII) }\end{array}$ & $\begin{array}{l}\text { Mishina et al. (1995), Gu et al. (1998, 1999), Beppu et al. } \\
\text { (2000), Oh et al. (2000), Larsson et al. (2001), Stenvers } \\
\text { et al. (2003) }\end{array}$ \\
\hline \multirow[t]{2}{*}{ Smads } & $\begin{array}{l}\text { Smad 1: failure of chorioallantoic fusion to produce } \\
\text { the umbilical connection to the placenta - due to } \\
\text { impaired allantois development and chorion over- } \\
\text { growth }\end{array}$ & Tremblay et al. (2001) \\
\hline & Smad 2, Smad 4, Smad 5 & $\begin{array}{l}\text { Weinstein et al. (1998), Yang et al. (1998), Chang et al. } \\
\text { (1999) }\end{array}$ \\
\hline \multicolumn{3}{|r|}{ (1) } \\
\hline \multirow{2}{*}{ Ligands } & TGF $\beta 1$ : $>50 \%$ die in utero, remainder perinatal & Shull et al. (1992) \\
\hline & Activin $\beta$ A, TGF $\beta 2$, TGF $\beta 3$, BMP-7 & $\begin{array}{l}\text { Dudley et al. (1995), Kaartinen et al. (1995), Matzuk } \\
\text { et al. (1995b), Proetzel et al. (1995), Sanford et al. (1997) }\end{array}$ \\
\hline \multirow[t]{2}{*}{ Receptors } & ActRIIB: minority survive and are fertile & Oh \& Li (1997) \\
\hline & TGF $\beta R I I$, follistatin & Matzuk et al. (1995a), Oshima et al. (1996) \\
\hline
\end{tabular}

BMP, bone morphogenetic protein; GDF, growth differentiation factor; MIS, Müllerian inhibitory substance; R, receptor; ALK, activin-receptor like kinase.

appear to accumulate around spiral arteries. A further population target and enter maternal spiral arterioles as endovascular (vEVTs) (Zhou et al. 1997). These form plugs in the arteries, blocking maternal blood flow and subsequently transform the maternal vessels into low-resistance vascular sinuses, capable of handling the high flow rate needed for placental perfusion throughout the second and third trimesters of pregnancy (Pijnenborg et al. 1983).

\section{Regulation of trophoblast invasion}

Trophoblast invasion of the decidua and maternal vasculature is regulated at least in part by decidual factors. Invading cytotrophoblasts express a repertoire of adhesion molecules, chemotactic receptors and proteases, which enable migration through the decidual matrix. Amongst these, MMPs have been highlighted as a family of proteases necessary for EVT invasion; in humans, MMP-2 is most closely linked to invasive 
potential in first trimester implantation sites and in primary trophoblast culture studies (Isaka et al. 2003, Bai et al. 2005, Jones et al. 2006). Decidual conditioned medium contains factors that have an overall stimulatory effect on cytotrophoblast cell motility (Bischof et al. 1994); a number of constituents have been individually examined and demonstrated to regulate the balance of invasion. As discussed earlier, activin A is abundantly secreted by decidual cells (Jones et al. 2002a) and exogenous activin A stimulates MMP-2 production by cytotrophoblast cells and promotes their outgrowth from villous tips in an in vitro model of EVT invasion (Caniggia et al. 1997a). This has been confirmed using primary cytotrophoblast cells in an in vitro invasion assay. Activin A stimulates the invasive potential of cytotrophoblasts isolated from placentae up to 10 weeks of gestation, whereas follistatin is inhibitory in late stage first trimester cytotrophoblasts (Bearfield et al. 2005). Activin expression by invasive cytotrophoblast cells is low in vivo (Jones et al. 2006), suggesting that maternally derived activin promotes trophoblast invasion (Fig. 2).

Conversely, TGF $\beta$ is a major repressor of cytotrophoblast outgrowth (Fig. 2). Unlike activin, TGF $\beta$ s are expressed by cytotrophoblast cells, co-expressed with TGF $\beta$ Rs (Schilling \& Yeh 2000). Whilst early publications reported a similar protein localisation for the different TGF $\beta$ isoforms at the maternal-foetal interface (Graham et al. 1992, Selick et al. 1994, Lysiak et al. 1995, Schilling \& Yeh 2000), the use of highly specific antibodies against the individual isoforms reveal cellspecific expression (Simpson et al. 2002), consistent with differential mRNA expression patterns (Ando et al. 1998). TGF $\beta 1$ and TGF $\beta 2$ are the most abundant isoforms in cytotrophoblast cell columns, but TGF $\beta 1$ is downregulated in invasive EVTs. TGF $\beta 2$ and TGF $\beta 3$ are present in the maternal tissues, with strong expression of TGF $\beta 2$ in decidual cells, whilst TGF $\beta 3$ is present only in immune cells. This is in marked contrast to findings from Caniggia et al. (1999), describing TGF $\beta 3$ production by first trimester trophoblast cells, and its selective upregulation in pre-eclamptic placentae. These inconsistencies may be methodological, due to differing antibody affinities or specificities. Alternatively, TGF $\beta 3$ may only be expressed in significant quantities in placental pathologies, an explanation that is supported by the fact that TGF $\beta 3$ mRNA is downregulated in normal first trimester decidua compared to non-pregnant endometrium (Ando et al. 1998).

In addition to their differential expression, in vitro studies suggest differential actions for the TGF $\beta$ isoforms in the implantation site (Fig. 2). TGF $\beta 1$ inhibits cytotrophoblast cell migration and invasiveness at least in part through the upregulation of the endogenous tissue inhibitors of MMPs (TIMPs)-1 and -2 (Graham \& Lala 1992, Karmakar \& Das 2002, Tse et al. 2002). In addition, TGF $\beta 1$ inhibits the invasion-promoting effects of hepatocyte growth factor (Caniggia et al. 1999). TGF 33 also potently inhibits trophoblast outgrowth, and inhibition of TGF $\beta 3$ expression or activity results in increased outgrowth, elevated MMP production/activity and fibronectin deposition (Caniggia et al. 1997b). Importantly, blockade of the excessive expression of TGF $\beta 3$ in pre-eclamptic placentae restores their invasive potential, supporting a role for TGF $\beta 3$ in the pathogenesis of this disorder. There are no reports in the literature describing an inhibitory effect of TGF $\beta 2$ on cytotrophoblast outgrowth. One potential explanation for the differential actions of the isoforms is that endoglin, an accessory receptor protein for TGF $\beta 1$ and TGF $\beta 3$, but not TGF $\beta 2$, has been shown to be necessary for the inhibitory effect of TGF $\beta$ on trophoblast differentiation (St-Jacques et al. 1994). Endoglin is specifically expressed by cytotrophoblast cells in the anchoring cell column that are undergoing differentiation, and is lost in the fully differentiated EVTs invading the decidua (Graham et al. 1992, Xu et al. 2002), suggesting an active participation in the differentiation process. However, TGF $\beta 2$, along with TGF $\beta 1$, exerts anti-proliferative effects on extravillous cells (Li \& Zhuang 1997). Subsequent experiments suggest this effect may be via inhibition of EGF-stimulated proliferation (Graham et al. 1994). Importantly, this growth inhibitory effect is lost in choriocarcinoma cells (e.g. JAR, JEG-3 cell lines), partially due to downregulation of endogenous Smad 3. This can be overcome by transfection with Smad 3 , as can the regulation of TIMP-1, however, these effects are insufficient to restore anti-invasive actions of TGF $\beta$ (Xu et al. 2003), indicating the importance of multiple downstream pathways for TGF $\beta$ in regulating trophoblast outgrowth. Interestingly, most of the immunoreactivity for TGF $\beta$ appears to be extracellular, suggesting it is sequestered in the matrix. This is consistent with TGF $\beta$ being bound to the proteoglycan decorin, which acts as a storage pool or negative regulator of TGF $\beta$ action. Indeed decorin is expressed in the decidua, and itself can attenuate cytotrophoblast outgrowth, in the presence of endogenous and exogenous TGF $\beta$ (Lysiak et al. 1995, Xu et al. 2002).

MIC-1 is also abundant at the implantation site, both in decidual cells as described earlier, and in the developing placenta (Moore et al. 2000, Marjono et al. 2003). In vitro studies using EVT cells indicate that MIC-1 has overall inhibitory actions on trophoblast invasion, through growth inhibition and stimulation of apoptosis (Morrish et al. 2001). The signalling pathway for MIC-1 has not been delineated, thus the degree of overlap with, or compensation for, TGF $\beta$ actions is unclear.

A role for nodal during placentation has been indicated by the abnormal placental development observed in the nodal null homozygous mouse (lannaccone et al. 1992). In the mid-gestation placenta, an excess of invasive giant cells are present, and overexpression of nodal in vitro is inhibitory to giant cell differentiation (Ma et al. 2001). In a human trophoblast cell line, overexpression of nodal decreases proliferation 
and increases apoptosis (Munir et al. 2004). The signalling pathways involved are unclear; nodal can signal via activin receptors (ALK-4/ActRIIB) or via ALK-7/ ActRIIB. Although both pathways result in activation of Smad 2/3, the former signalling pathway requires cripto as a co-receptor. Cripto is abundantly expressed in the developing embryo (Dono et al. 1993, Baldassarre et al. 2001) in concert with Nodal, however, its expression by the placenta has not been fully elucidated (Baldassarre et al. 2001). Conversely, ALK-7 is expressed by the placenta, and is specifically upregulated after the first trimester, following similar expression dynamics as nodal (Roberts et al. 2003). A soluble form of ALK-7 is also abundant from mid-gestation, implying that nodal signalling is tightly regulated in the latter half of pregnancy; its actions throughout pregnancy are currently under investigation.

\section{Regulation of placental development and function}

Activin, TGF $\beta$ and MIC- 1 are abundantly expressed by ST cells of the placental villi (Qu \& Thomas 1995, Simpson et al. 2002, Marjono et al. 2003). Activin A and inhibin A are detectable in newly fusing syncytium, in vivo and in vitro (Debieve et al. 2000, Jones et al. 2006), indicating a potential involvement in cytotrophoblast fusion and syncytialisation, whilst TGF $\beta$ is a potent inhibitor of this process (Morrish et al. 1991). In contrast, low concentrations of MIC-1 induce syncytialisation of cytotrophoblast cells (Morrish et al. 2001). Furthermore, treatment of human embryonic stem cells with BMP-4 upregulates hCG production, indicating the formation of ST (Xu 2006, Fig. 2).

TGF $\beta$ superfamily members also have roles in regulating placental hormone production (Fig. 2): activin A stimulates, whilst TGF $\beta$ inhibits the production and/or secretion of hCG, human placental lactogen, progesterone and oestradiol (Petraglia et al. 1989, Song et al. 1996, Luo et al. 2002, Morrish et al. 1991). BMP-7/ osteogenic protein- 1 is expressed by cytotrophoblast cells rather than by the ST, but appears to play a negative paracrine role in steroidogenesis (Martinovic et al. 1996). In contrast to its low expression in the uterus, inhibin $A$ is abundantly produced by the placenta $(\mathrm{Qu} \&$ Thomas 1995). This is predominantly due to syncytial expression, and its co-expression with beta-glycan (Jones et al. 2002b, Ciarmela et al. 2003) is consistent with inhibin acting as a functional antagonist for activin in the placenta. Indeed, inhibin A potently inhibits steroidogenesis and production of hCG by the ST (Petraglia et al. 1989). Other roles for inhibin and activin during pregnancy are indicated by their high concentrations in circulating maternal blood, increasing with gestational age (Woodruff et al. 1997). Follistatin levels also rise, but to a lesser degree in the third trimester, suggesting that activin A may be biologically active as an endocrine factor in late pregnancy. Further increases in inhibin and activin A levels are detectable around the onset of parturition, suggesting potential roles in the cascade of events during labour (Muttukrishna et al. 1995).

\section{Inhibins and activins in placental pathologies}

As their major source is the placenta, both inhibins and activins have been explored as potential candidates for screening or diagnostic tests for pregnancy disorders. Inhibin A is a particularly specific marker of early placental development, and is detectable from 14 days postembryo transfer following IVF, indicating its potential as an early marker of IVF success (Birdsall et al. 1997). Conversely, a low level of inhibin A in early pregnancy is indicative of pregnancy failure, and several studies have shown a clear correlation between low inhibin A levels and subsequent miscarriage (Wallace et al. 2004, Prakash et al. 2005). Analysis of inhibin $\alpha$ mRNA and protein in placental tissue demonstrates that expression levels are unaltered; instead low levels are likely to be representative of low placental mass (Muttukrishna et al. 2004). For this reason, it has also been suggested that presence of elevated inhibin A levels may be employed to assess retention of trophoblast cells following molar pregnancies (Florio et al. 2002). MIC-1 has also proven to be successful in terms of identifying failing pregnancies: maternal serum levels are significantly lower in those women who subsequently miscarry, suggesting MIC-1 may be a biochemical and predictive marker of placental malfunction (Tong et al. 2004).

An elevated maternal serum level of inhibin $A$ in the second trimester of pregnancy is indicative of foetal Down's syndrome, and has been adopted in some centres in combination with other markers (e.g. hCG, $\alpha$ feto-protein (AFP)) as an adjunct screening test (Aitken et al. 1996, Wallace et al. 1996, Malone et al. 2005) to assess risk prior to amniocentesis or chorionic villus sampling. High serum levels of inhibin A and activin A have also been reported in women with pre-eclampsia (PET) (Bersinger et al. 2003), a serious pregnancy complication, characterized by severe maternal hypertension and systemic inflammation and endothelial dysfunction, that remains the leading cause of foetal and maternal morbidity and mortality. Importantly, activin levels have been shown to be elevated prior to the onset of maternal symptoms (Muttukrishna et al. 2000). The combined measurement of placental factors (e.g. hCG, pregnancy associated placental protein-A, AFP, oestriol) together with Doppler ultrasound analysis of uterine artery blood flow, has been trialled as a potential screening test in the second trimester. Addition of serum inhibin A and/or activin A levels can improve predictive efficacy (Ay et al. 2005, Madazli et al. 2005, Spencer et al. 2006), particularly of early onset PET (Muttukrishna et al. 2000), but so far does not appear to be of great clinical significance. The roles that inhibins and activins play in the pathogenesis of PET are not 
understood, although the elevation of placental of inhibin/activin $\alpha$ and $\beta A$ subunits, in the absence of elevated follistatin, indicates increased levels of bioactive activin within the feto-placental unit (Casagrandi et al. 2003). Activin A levels are also elevated in maternal serum in pregnancies complicated by intrauterine growth restriction (Wallace et al. 2003), suggesting that abnormal inhibin/activin levels may be useful as a screening tool for high risk pregnancies requiring greater obstetric attention.

\section{Regulation of uterine immune responses}

Both activin A and TGF $\beta$ also have immunomodulator$y /$ inflammatory actions. This is of potential importance in regard to their functions in the endometrium - a site of highly specialised immune responses. TGF $\beta$ fulfils a pivotal role in the peripheral immune system through mediating the acquisition of immune tolerance (Schmidt-Weber \& Blaser 2004). Tolerance is essential for preventing inappropriate immune responses, for example, to self-antigens, and is undoubtedly a significant component of the uterine immune environment, enabling embryo implantation and gestation. Elegant experiments in the mouse have demonstrated an interaction between seminal plasma and the endometrial mucosa. Immediately after mating, seminal plasma triggers an acute inflammatory response - involving recruitment of antigen presenting cells and controlled cytokine (e.g. GM-CSF, chemokines) production proposed to instigate the tolerance response to paternal antigens (Robertson et al. 1997, Johansson et al. 2004). TGF $\beta$ is a major constituent of seminal plasma in rodents and humans, and appears to be a major contributor to these actions (Robertson et al. 2002). Recent studies of effects of seminal plasma on epithelial cells in culture suggest similar mechanisms may take place in the human reproductive tract (Gutsche et al. 2003). In addition, TGF $\beta$ can inhibit Thelper type 1 (Th1) responses, which may be detrimental to pregnancy (Raghupathy 2001), and is an important regulator of NK cell behaviour, downregulating IFN- $\gamma$ induced activation and inflammatory cytokine production (Rook et al. 1986). TGF $\beta 2$ is abundantly produced by uterine-specific NK cells (Clark et al. 1994, Nagaeva et al. 2002), where it may be involved in the generation of their low cytotoxic and immunosuppressive phenotype (Saito et al. 1993, Eriksson et al. 2004, Fig. 2). Indeed in mice prone to a high pregnancy failure rate, TGF $\beta$ mRNA is significantly decreased in both uterine epithelial and metrial gland (NK) cells (Gorivodsky et al. 1999). Thus, TGF $\beta$ actions in the peri-implantation endometrium - both endogenously from endometrial and leukocyte expression, and exogenously from seminal plasma - potentially are instrumental in the establishment of anti-rejection strategies to allow implantation of the semi-allogeneic embryo. An immunomodulatory role for MIC-1 has also been proposed, as an overall immunosuppressive factor, due to its high maternal serum concentrations during pregnancy (Moore et al. 2000). Although its expression by uterine immune cells has not been described, MIC- 1 is abundantly produced by the placenta, and is present in very high concentrations in amniotic fluid, suggesting systemic and intrauterine anti-inflammatory/ immunosuppressive actions.

Activin A has also roles within the systemic immune system; it was first described as erythroid differentiation factor (Murata et al. 1988), responsible for promoting erythropoiesis, regulating $\mathrm{B}$ lymphocyte generation (Zipori \& Barda-Saad 2001) and promoting mast cell differentiation and migration in vitro (Funaba et al. 2003). Activin $\mathrm{A}$ is also involved in inflammatory reactions: elevated activin A levels are associated with inflammatory pathologies in humans (Yu \& Dolter 1997), and activin A is acutely and transiently released into the peripheral circulation after an inflammatory insult in sheep models (Jones et al. 2004). This precedes the elevation in serum tumour necrosis factor- $\alpha$, indicating pro-inflammatory actions. Previous studies examining the effect of activin on systemic and local cytokine production have produced conflicting evidence, suggesting that activin possesses both pro- and anti-inflammatory qualities (de Kretser et al. 1999, Keelan et al. 2000).

\section{Regulation of menstruation and repair}

It is, therefore, not surprising that activin $A$ and TGF $\beta$ are also abundant in the pre-menstrual endometrium, corresponding to immune cell infiltration and other inflammatory events. Activin $\beta$ A subunits are intensely expressed by neutrophils and macrophages in the premenstrual and menstrual endometrium (Leung et al. 1998), whilst TGF $\beta$ is expressed by endometrial immune cells (Lea \& Clark 1991). Leukocytes are probably effectors of endometrial breakdown (Salamonsen \& Lathbury 2000), and a number of actions for activin and TGF $\beta$ could be envisaged in this process, through autocrine or paracrine upregulation of MMPs and cytokines. Whilst activin A could promote endometrial breakdown via upregulation of MMPs in endometrial cells and leukocytes (Ogawa et al. 2000, Jones et al. 2006), TGF $\beta$ is an established suppressor of MMP production by endometrial cells (Fig. 2). Progesterone acts as a 'blanket-repressor' of the majority of MMPs to prevent precocious endometrial breakdown, during the preparation for implantation, and TGF $\beta$ has been demonstrated to fulfil a critical role as a paracrine transducer of progesterone action (Osteen et al. 2003). This suppressive effect is overcome by the production of TGF $\beta$ antagonist lefty A, first described as endometrial bleeding-associated factor (Kothapalli et al. 1997). Lefty A antagonises TGF $\beta$ signalling at the level of the type II receptor and by interference with Smad 2 
phosphorylation, and its dramatic upregulation in the perimenstrual phase is coincident with the release of MMP suppression (Tabibzadeh 2002). Furthermore, in vitro, lefty A directly stimulates the expression of proMMP-3 and -7 (Cornet et al. 2002).

In addition to inflammatory actions, both activin $\mathrm{A}$ and TGF $\beta$ have apparently contrasting roles in the resolution of inflammation and wound healing. TGF $\beta$ isoforms are selectively expressed during wound healing (reviewed by O'Kane \& Ferguson (1997)). TGF $\beta 1$ and TGF $\beta 2$ are acutely upregulated after wounding, followed by an upregulation and dominant expression of TGF $\beta 3$. The healing process is dependent on isoform-specific functions, TGF $\beta 3$ instrumental for wound closure and collagen deposition. Neutralisation of TGF $\beta 1$ and TGF $\beta 2$ activity results in decreased scarring (Shah et al. 1994), and indeed the temporal shift in isoform expression during wound healing, that is an elevated ratio of TGF $\beta 3: T G F \beta 1$, appears to be critical for minimal scarring. Differential activin expression is also integral to the wound healing process. In skin wounds, activin $\beta A$ is acutely upregulated in the wound site particularly in infiltrating immune cells, followed by an upregulation in $\beta B$ subunits in migrating keratinocytes that is maintained until wound closure (Munz et al. 1999a). Overexpression of activin $\beta A$ in the mouse epidermis accelerates wounding healing and scarring (Munz et al. 1999b), whilst overexpression of follistatin in keratinocytes results in delayed healing, and also in a reduction in collagen scar tissue deposition (Wankell et al. 2001). The importance of TGF $\beta$ and activin in modulating tissue repair are further confirmed by the phenotype of the Smad 3 knockout mouse, which conversely experiences accelerated healing, characterised by reduced inflammation and scar deposition (Ashcroft et al. 1999). Overall, these mediators are clearly important, but act in a tightly coordinated manner, both spatially and temporally, to mediate wound healing.

Interestingly, the pattern of $\beta \mathrm{A}$ and $\beta \mathrm{B}$ expression in peri-menstrual endometrium is markedly similar to that in wound healing, with $\beta$ A-expressing inflammatory cells infiltrating in the acute inflammatory response, whilst $\beta \mathrm{B}$-positive macrophages are resident in the endometrium during endometrial regeneration and proliferation (Jones et al. 2000). These contrasting expression patterns suggest differential actions for activin $A$ and $B$ in the endometrium during menstruation and endometrial repair. TGF $\beta$ expression during endometrial repair has not been closely examined, although recent in vitro studies of wound repair using endometrial stroma provide some evidence for modulatory effects of TGF $\beta$ on stromal cell motility and collagen gel contractility (Nasu et al. 2005).

\section{Summary}

This review describes the expression and potential roles for a number of TGF $\beta$ superfamily members in the uterus and placenta. The actions of activins and TGF $\beta$ s have been studied in the greatest depth, leading to proposed roles in modulating cell turnover and tissue remodelling across the menstrual cycle and during the establishment of pregnancy. Interestingly, activins and TGF $\beta$ s often appear to have opposing actions, indicating that a greater degree of specificity exists in the downstream signalling pathways of these two closely related ligands that are claimed to utilise the same Smads. More recently, the expression of a number of less wellknown TGF $\beta$ superfamily ligands by the uterus, embryo and placenta has been described. Their involvement in endometrial biology and the events involved in the establishment of pregnancy is not surprising, given their association with dynamic cellular/tissue development. The identification of receptors, binding proteins and accessory/soluble receptors by endometrial and placental cells reinforces the tight regulation of action that is so characteristic of the TGF $\beta$ superfamily. Further complexity exists within this family, as ligands are synthesised as inactive proforms, requiring activating by photolytic enzymes (e.g. furin), meaning that proof of synthesis does not necessarily demonstrate biological activity. Future descriptive, biochemical and functional studies (in vitro and in vivo) will undoubtedly produce a greater understanding of the ever-expanding roles for, and complex interactions of, these factors in relation to reproductive biology.

\section{Acknowledgements}

We acknowledge the assistance of Ms S Panckridge with illustrations. Work from the authors' laboratory cited here was funded by a program grant (no. 241000). L A S and J K F are supported by fellowships from the NHMRC (Australia) (nos 198705 and 143798). The authors declare that there is no conflict of interest that would prejudice the impartiality of this scientific work.

\section{References}

Aitken DA, Wallace EM, Crossley JA, Swanston IA, van Pareren Y, van Maarle M, Groome NP, Macri JN \& Connor JM 1996 Dimeric inhibin a as a marker for down's syndrome in early pregnancy. New England Journal of Medicine 334 1231-1236.

Albano RM, Groome N \& Smith JC 1993 Activins are expressed in preimplantation mouse embryos and in ES and EC cells and are regulated on their differentiation. Development 117 711-723.

Alexander CM, Hansell EJ, Behrendtsen O, Flannery ML, Kishnani NS, Hawkes SP \& Werb Z 1996 Expression and function of matrix metalloproteinases and their inhibitors at the maternal-embryonic boundary during mouse embryo implantation. Development 122 1723-1736.

Ando N, Hirahara F, Fukushima J, Kawamoto S, Okuda K, Funabashi T, Gorai I \& Minaguchi H 1998 Differential gene expression of TGFbeta isoforms and TGF-beta receptors during the first trimester of pregnancy at the human maternal-fetal interface. American Journal of Reproduction Immunology 40 48-56. 
Ashcroft GS, Yang X, Glick AB, Weinstein M, Letterio JL, Mizel DE, Anzano M, Greenwell-Wild T, Wahl SM, Deng C, et al. 1999 Mice lacking Smad3 show accelerated wound healing and an impaired local inflammatory response. Nature Cell Biology 1 260-266.

Ay E, Kavak ZN, Elter K, Gokaslan H \& Pekin T 2005 Screening for preeclampsia by using maternal serum inhibin $A$, activin $A$, human chorionic gonadotropin, unconjugated estriol, and alpha-fetoprotein levels and uterine artery Doppler in the second trimester of pregnancy. Australian and New Zealand Journal of Obstetrics and Gynaecology 45 283-288.

Bai SX, Wang YL, Qin L, Xiao ZJ, Herva R \& Piao YS 2005 Dynamic expression of matrix metalloproteinases (MMP-2, -9 and -14) and the tissue inhibitors of MMPs (TIMP-1, -2 and -3) at the implantation site during tubal pregnancy. Reproduction 129 103-113.

Baldassarre G, Tucci $M$, Lembo G, Pacifico FM, Dono R, Lago CT, Barra A, Bianco C, Viglietto G, Salomon D, et al. 2001 A truncated form of teratocarcinoma-derived growth factor-1 (cripto-1) mRNA expressed in human colon carcinoma cell lines and tumors. Tumour Biology 22 286-293.

Bearfield C, Jauniaux E, Groome N, Sargent IL \& Muttukrishna S 2005 The secretion and effect of inhibin A, activin A and follistatin on first-trimester trophoblasts in vitro. Journal of Endocrinology 152 909-916.

Behringer RR, Finegold MJ \& Cate RL 1994 Mullerian-inhibiting substance function during mammalian sexual development. Cell 79 415-425.

Beppu H, Kawabata M, Hamamoto T, Chytil A, Minowa O, Noda T \& Miyazono K 2000 BMP type II receptor is required for gastrulation and early development of mouse embryos. Developmental Biology 221 249-258.

Bersinger NA, Smarason AK, Muttukrishna S, Groome NP \& Redman CW 2003 Women with preeclampsia have increased serum levels of pregnancy-associated plasma protein A (PAPP-A), inhibin A, activin $A$ and soluble E-selectin. Hypertension in Pregnancy 22 45-55.

Birdsall M, Ledger W, Groome N, Abdalla H \& Muttukrishna S 1997 Inhibin $\mathrm{A}$ and activin $\mathrm{A}$ in the first trimester of human pregnancy. Journal of Clinical Endocrinology and Metabolism 82 1557-1560.

Bischof P, Martelli M \& Campana A 1994 The regulation of endometrial and trophoblastic metalloproteinases during blastocyst implantation. Contraception, Fertilité, Sexualité 22 48-52.

Brown CW, Houston-Hawkins DE, Woodruff TK \& Matzuk MM 2000 Insertion of Inhbb into the Inhba locus rescues the Inhba-null phenotype and reveals new activin functions. Nature Genetics $\mathbf{2 5}$ 453-457.

Bulmer JN, Pace D \& Ritson A 1988 Immunoregulatory cells in human decidua: morphology, immunohistochemistry and function. Reproduction, Nutrition, Development 28 1599-1613.

Caniggia I, Lye SJ \& Cross JC 1997a Activin is a local regulator of human cytotrophoblast cell differentiation. Endocrinology 138 3976-3986.

Caniggia I, Taylor CV, Ritchie JW, Lye SJ \& Letarte M 1997b Endoglin regulates trophoblast differentiation along the invasive pathway in human placental villous explants. Endocrinology 138 4977-4988.

Caniggia I, Grisaru-Gravnosky S, Kuliszewsky M, Post M \& Lye SJ 1999 Inhibition of TGF-beta 3 restores the invasive capability of extravillous trophoblasts in preeclamptic pregnancies. European Journal of Clinical Investigation 103 1641-1650.

Casagrandi D, Bearfield C, Geary J, Redman CW \& Muttukrishna S 2003 Inhibin, activin, follistatin, activin receptors and beta-glycan gene expression in the placental tissue of patients with preeclampsia. Molecular Human Reproduction 9 199-203.

Chang H, Huylebroeck D, Verschueren K, Guo Q, Matzuk MM \& Zwijsen A 1999 Smad5 knockout mice die at mid-gestation due to multiple embryonic and extraembryonic defects. Development 126 1631-1642.

Chang H, Brown CW \& Matzuk MM 2002 Genetic analysis of the mammalian transforming growth factor-beta superfamily. Endocrine Reviews 23 787-823.
Chow JF, Lee KF, Chan ST \& Yeung WS 2001 Quantification of transforming growth factor beta1 (TGFbeta1) mRNA expression in mouse preimplantation embryos and determination of TGFbeta receptor (type I and type II) expression in mouse embryos and reproductive tract. Molecular Human Reproduction. 7 1047-1056.

Ciarmela P, Florio P, Toti P, Grasso D, Santopietro R, Tosi P \& Petraglia F 2003 Expression of betaglycan in pregnant tlssues throughout gestation. European Journal of Endocrinology 149 433-437.

Clark DA, Vince G, Flanders KC, Hirte H \& Starkey P 1994 CD56+ lymphoid cells in human first trimester pregnancy decidua as a source of novel transforming growth factor-beta 2-related immunosuppressive factors. Human Reproduction 9 2270-2277.

Conlon FL, Lyons KM, Takaesu N, Barth KS, Kispert A, Herrmann B \& Robertson EJ 1994 A primary requirement for nodal in the formation and maintenance of the primitive streak in the mouse. Development 120 1919-1928.

Cornet PB, Picquet C, Lemoine P, Osteen KG, Bruner-Tran KL, Tabibzadeh S, Courtoy PJ, Eeckhout Y, Marbaix E \& Henriet P 2002 Regulation and function of LEFTY-A/EBAF in the human endometrium. mRNA expression during the menstrual cycle, control by progesterone, and effect on matrix metalloprotineases. Journal of Biological Chemistry 277 42496-42504.

Croy BA, Esadeg S, Chantakru S, van den Heuvel M, Paffaro VA, He H, Black GP, Ashkar AA, Kiso Y \& Zhang J 2003 Update on pathways regulating the activation of uterine Natural Killer cells, their interactions with decidual spiral arteries and homing of their precursors to the uterus. Journal of Reproductive Immunology $\mathbf{5 9}$ 175-191.

Daluiski A, Engstrand T, Bahamonde ME, Gamer LW, Agius E, Stevenson SL, Cox K, Rosen V \& Lyons LM 2001 Bone morphogenetic protein-3 is a negative regulator of bone density. Nature Genetics 27 84-88.

Debieve F, Pampfer S \& Thomas K 2000 Inhibin and activin production and subunit expression in human placental cells cultured in vitro. Molecular Human Reproduction 6 743-749.

Debieve F, Hinck L, Biard JM, Bernard P \& Hubinont C 2006 Activin receptor expression and induction of apoptosis in rat blastocysts in vitro. Human Reproduction 21 618-623.

Dong J, Albertini DF, Nishimori K, Kumar TR, Lu N \& Matzuk MM 1996 Growth differentiation factor-9 is required during early ovarian folliculogenesis. Nature 383 531-535.

Dono R, Scalera L, Pacifico F, Acampora D, Persico MG \& Simeone A 1993 The murine cripto gene: expression during mesoderm induction and early heart morphogenesis. Development 118 1157-1168.

Dudley AT, Lyons KM \& Robertson EJ 1995 A requirement for bone morphogenetic protein-7 during development of the mammalian kidney and eye. Genes \& Development 9 2795-2807.

Durlinger AL, Gruijters MJ, Kramer P, Karels B, Kumar TR, Matzuk MM, Rose UM, de Jong FH, Uilenbroek JT, Grootegoed JA, et al. 2001 Anti-Mullerian hormone attenuates the effects of FSH on follicle development in the mouse ovary. Endocrinology 142 4891-4899.

Eriksson M, Meadows SK, Wira CR \& Sentman CL 2004 Unique phenotype of human uterine NK cells and their regulation by endogenous TGF-beta. Journal of Leukocyte Biology 76 667-675.

Ferenczy A 1976 Studies on the cytodynamics of human endometrial regeneration II. Transmission electron microscopy and histochemistry. American Journal of Obstetrics and Gynecology 124 582-595.

Florio P, Severi FM, Cobellis L, Danero S, Bome A, Luisi S, Petraglia F, et al. 2002 Serum activin A and inhibin A. New clinical markers for hydatidiform mole. Cancer 94 2618-2622.

Funaba M, Ikeda T, Ogawa K, Murakami M \& Abe M 2003 Role of activin $\mathrm{A}$ in murine mast cells: modulation of cell growth, differentiation, and migration. Journal of Leukocyte Biology 73 793-801.

Godkin JD \& Dore JJ 1998 Transforming growth factor beta and the endometrium. Reviews of Reproduction 3 1-6.

Gold LI, Saxena B, Mittal KR, Marmor M, Goswami S, Nactigal L, Kore M \& Demopoulos RI 1994 Increased expression of transforming growth factor beta isoforms and basic fibroblast growth factor in complex 
hyperplasia and adenocarcinoma of the endometrium: evidence for paracrine and autocrine action. Advances in Cancer Research $\mathbf{5 4}$ 2347-2358.

Gorivodsky M, Torchinsky A, Zemliak I, Savion S, Fein A \& Toder V 1999 TGF beta 2 mRNA expression and pregnancy failure in mice. American Journal of Reproductive Immunology 42 124-133.

Graham CH, Lysiak JJ, McCrae KR \& Lala PK 1992 Localization of transforming growth factor-beta at the human fetal-maternal interface: role in trophoblast growth and differentiation. Biology of Reproduction 46 561-572.

Graham CH, Connelly I, MacDougall JR, Kerbel RS, Stetler-Stevenson WG \& Lala PK 1994 Resistance of malignant trophoblast cells to both the anti-proliferative and anti-invasive effects of transforming growth factor-beta. Experimental Cell Research 214 93-99.

Graham CH \& Lala PK 1992 Mechanisms of placental invasion of the uterus and their control. Biochemistry and Cell Biology 70 867-874.

Gu Y, Srivastava RK, Ou J, Krett NL, Mayo KE \& Gibori G 1995 Cellspecific expression of activin and its two binding proteins in the rat decidua: role of alpha 2-macroglobulin and follistatin. Endocrinology 136 3815-3822.

Gu Z, Nomura M, Simpson BB, Lei H, Feijen A, van den Eijnden-van Raaij J, Donahoe PK \& Li E 1998 The type I activin receptor ActRIB is required for egg cylinder organization and gastrulation in the mouse. Genes \& Development. 12 844-857.

Gu Z, Reynolds EM, Song J, Lei H, Feijen A, Yu L, He W, MacLaughlin DT, van den Eijnden-van Raaij J, Donahoe PK, et al. 1999 The type I serine/threonine kinase receptor ActRIA (ALK2) is required for gastrulation of the mouse embryo. Development 126 2551-2561.

Gutsche S, von Wolff M, Strowitzki T \& Thaler CJ 2003 Seminal plasma induces mRNA expression of IL-1beta, IL-6 and LIF in endometrial epithelial cells in vitro. Molecular Human Reproduction 9 785-791.

Hamilton WJ \& Boyd JD 1960 Development of the human placenta in the first three months of gestation. Journal of Anatomy. 94 297-328.

He ZY, Liu HC, Mele CA, Barmat L, Veeck LL, Davis O \& Rosenwaks Z 1999 Expression of inhibin/activin subunits and their receptors and binding proteins in human preimplantation embryos. Journal of Assisted Reproduction and Genetics 16 73-80.

Hsiao EC, Koniaris LG, Zimmers-Koniaris T, Sebald SM, Huynh TV \& Lee S) 2000 Characterization of growth-differentiation factor 15, a transforming growth factor beta superfamily member induced following liver injury. Molecular and Cellular Biology 20 3742-3751.

lannaccone PM, Zhou X, Khokha M, Boucher D \& Kuehn MR 1992 Insertional mutation of a gene involved in growth regulation of the early mouse embryo. Developmental Dynamics 194 198-208.

Isaka K, Usuda S, Ito H, Sagawa Y, Nakamura H, Nishi H, Suzuki Y, Li YF \& Takayama M 2003 Expression and activity of matrix metalloproteinase 2 and 9 in human trophoblasts. Placenta 24 53-64.

Johansson M, Bromfield JJ, Jasper MJ \& Robertson SA 2004 Semen activates the female immune response during early pregnancy in mice. Immunology 112 290-300.

Jones RL, Salamonsen LA, Critchley HO, Rogers PA, Affandi B \& Findlay JK 2000 Inhibin and activin subunits are differentially expressed in endometrial cells and leukocytes during the menstrual cycle, in early pregnancy and in women using progestin-only contraception. Molecular Human Reproduction 6 1107-1117.

Jones RL, Salamonsen LA \& Findlay JK 2002a Activin A promotes human endometrial stromal cell decidualization in vitro. Journal of Clinical Endocrinology and Metabolism 87 4001-4004.

Jones RL, Salamonsen LA, Zhao YC, Ethier JF, Drummond AE \& Findlay JK $2002 b$ Expression of activin receptors, follistatin and betaglycan by human endometrial stromal cells; consistent with a role for activins during decidualization. Molecular Human Reproduction 8 363-374.

Jones KL, de Kretser DM, Patella S \& Phillips DJ 2004 Activin A and follistatin in systemic inflammation. Molecular and Cellular Endocrinology 225 119-125.

Jones RL, Findlay JK, Farnworth PG, Robertson DM, Wallace E \& Salamonsen LA 2006 Activin A and inhibin A differentially regulate human uterine matrix metalloproteinases: potential interactions during decidualization and trophoblast invasion. Endocrinology 147 724-732.

Jornvall H, Reissmann E, Andersson O, Mehrkash M \& Ibanez CF 2004 ALK7, a receptor for nodal, is dispensable for embryogenesis and left-right patterning in the mouse. Molecular and Cellular Biology 24 9383-9389.

Kaartinen V, Voncken JW, Shuler C, Warburton D, Bu D, Heisterkamp N \& Groffen J 1995 Abnormal lung development and cleft palate in mice lacking TGF-beta 3 indicates defects of epithelial-mesenchymal interaction. Nature Genetics 11 415-421.

Kamijo T, Rajabi MR, Mizunuma H \& Ibuki Y 1998 Biochemical evidence for autocrine/paracrine regulation of apoptosis in cultured uterine epithelial cells during mouse embryo implantation in vitro. Molecular Human Reproduction 4 990-998.

Karmakar S \& Das C 2002 Regulation of trophoblast invasion by IL1 beta and TGF-beta1. American Journal of Reproductive Immunology 48 210-219.

Keelan JA, Zhou RL \& Mitchell MD 2000 Activin A exerts both pro- and anti-inflammatory effects on human term gestational tissues. Placenta 21 38-43.

Kim MR, Park DW, Lee JH, Choi DS, Hwang KJ, Ryu HS \& Min CK 2006 Progesterone-dependent release of transforming growth factor-beta1 from epithelial cells enhances the endometrial decidualization by turning on the Smad signalling in stromal cells. Molecular Human Reproduction 11 801-808.

King A, Burrows T, Verma S, Hiby S \& Loke YW 1998 Human uterine lymphocytes. Human Reproductive Update 4 480-485.

King A, Hiby SE, Gardner L, Joseph S, Bowen JM, Verma S, Burrows TD \& Loke YW 2000 Recognition of trophoblast HLA class I molecules by decidual NK cell receptors-a review. Placenta 21 (Supplement A) S81-S85.

Kothapalli R, Buyuksal I, Wu SQ, Chegini N \& Tabibzadeh S 1997 Detection of ebaf, a novel human gene of the transforming growth factor beta superfamily association of gene expression with endometrial bleeding. Journal of Clinical Investigation $992342-$ 2350.

de Kretser DM, Hedger MP \& Phillips DJ 1999 Activin A and follistatin: their role in the acute phase reaction and inflammation. Journal of Endocrinology 161 195-198.

Kubota T, Taguchi M, Kobayashi K, Masuda M \& Aso T 1997 Relationship between the release of prolactin and endothelin-1 in human decidualized endometrial cells. European Journal of Endocrinology 137 200-204.

Larsson J, Goumans MJ, Sjostrand LJ, van Rooijen MA, Ward D, Leveen P, Xu X, ten Dijke P, Mummery CL \& Karlsson S 2001 Abnormal angiogenesis but intact hematopoietic potential in TGF-beta type I receptor-deficient mice. EMBO Journal 20 1663-1673.

Lau AL, Kumar TR, Nishimori K, Bonadio J \& Matzuk MM 2000 Activin betaC and betaE genes are not essential for mouse liver growth, differentiation, and regeneration. Molecular Cell Biology 20 6127-6137.

Lea R \& Clark D 1991 Macrophages and migratory cells in endometrium relevant to implantation. Baillieres Clinical Obstetrics \& Gynaecology 5 25-59.

Leung PH, Salamonsen LA \& Findlay JK 1998 Immunolocalization of inhibin and activin subunits in human endometrium across the menstrual cycle. Human Reproduction 13 3469-3477.

Li RH \& Zhuang LZ 1997 The effects of growth factors on human normal placental cytotrophoblast cell proliferation. Human Reproduction 12 830-834.

Lim J, Bongso A \& Ratnam S 1993 Mitogenic and cytogenetic evaluation of transforming growth factor-beta on murine preimplantation embryonic development in vitro. Molecular Reproduction and Development. 36 482-487.

Liu G, Lin H, Zhang X, Li Q, Wang H, Qian D, Ni J \& Zhu C 2004 Expression of Smad2 and Smad4 in mouse uterus during the oestrous cycle and early pregnancy. Placenta 25 530-537. 
Lu RZ, Matsuyama S, Nishihara M \& Takahashi M 1993 Developmental expression of activin/inhibin beta A, beta B, and alpha subunits, and activin receptor-IIB genes in preimplantation mouse embryos. Biology of Reproduction 49 1163-1169.

Luo S, Yu H, Wu D \& Peng C 2002 Transforming growth factor-beta1 inhibits steroidogenesis in human trophoblast cells. Molecular Human Reproduction 8 318-325.

Lysiak JJ, Hunt J, Pringle GA \& Lala PK 1995 Localization of transforming growth factor beta and its natural inhibitor decorin in the human placenta and decidua throughout gestation. Placenta 16 221-231.

Ma GT, Soloveva V, Tzeng SJ, Lowe LA, Pfendler KC, lannaccone PM, Kuehn MR \& Linzer DI 2001 Nodal regulates trophoblast differentiation and placental development. Developmental Biology 236 124-135.

Madazli R, Kuseyrioglu B, Uzun H, Uludag S \& Ocak V 2005 Prediction of preeclampsia with maternal mid-trimester placental growth factor, activin A, fibronectin and uterine artery doppler velocimetry. International Journal of Gynaecology and Obstetrics 89 251-257.

Malone FD, Canick JA, Ball RH, Nyberg DA, Comstock CH, Bukowski R, Berkowitz RL, Gross SJ, Dugoff L \& Craigo SD 2005 First-trimester or second-trimester screening, or both, for down's syndrome. New England Journal of Medicine $3532001-$ 2011.

Marjono AB, Brown DA, Horton KE, Wallace EM, Breit SN \& Manuelpillai U 2003 Macrophage inhibitory cytokine-1 in gestational tissues and maternal serum in normal and pre-eclamptic pregnancy. Placenta 24 100-106.

Martinovic S, Latin V, Suchanek E, Stavljenic-Rukavina A, Sampath KI \& Vukicevic S 1996 Osteogenic protein-1 is produced by human fetal trophoblasts in vivo and regulates the synthesis of chorionic gonadotropin and progesterone by trophoblasts in vitro. European Journal of Clinical Chemistry Clinical Biochemistry 34 103-109.

Matzuk MM, Finegold MJ, Su JG, Hsueh AJ \& Bradley A 1992 Alphainhibin is a tumour-suppressor gene with gonadal specificity in mice. Nature 360 313-319.

Matzuk MM, Lu N, Vogel H, Sellheyer K, Roop DR \& Bradley A 1995a Multiple defects and perinatal death in mice deficient in follistatin. Nature 374 360-363.

Matzuk MM, Kumar TR, Vassalli A, Bickenbach JR, Roop DR, Jaenisch R \& Bradlely A $1995 b$ Jaenisch R \& Bradley A Functional analysis of activins during mammalian development. Nature $\mathbf{3 7 4}$ 354-356.

McPherron AC, Lawler AM \& Lee SJ 1997 Regulation of skeletal muscle mass in mice by a new TGF-beta superfamily member. Nature 387 83-90.

McPherron AC, Lawler AM \& Lee SJ 1999 Regulation of anterior/posterior patterning of the axial skeleton by growth/differentiation factor 11. Nature Genetics 22 260-264.

Meno C, Shimono A, Saijoh Y, Yashiro K, Mochida K, Ohishi S, Noji S, Kondoh H \& Hamada H 1998 Lefty-1 is required for left-right determination as a regulator of lefty-2 and nodal. Cell 94 287-297.

Meno C, Gritsman K, Ohishi S, Ohfuji Y, Heckscher E, Mochida K, Shimono A, Kondoh H, Talbot WS, Robertson EJ, et al. 1999 Mouse Lefty2 and zebrafish antivin are feedback inhibitors of nodal signaling during vertebrate gastrulation. Journal of Molecular Cell 4 287-298.

Mishina Y, Suzuki A, Ueno N \& Behringer RR 1995 Bmpr encodes a type I bone morphogenetic protein receptor that is essential for gastrulation during mouse embryogenesis. Genes Development 9 3027-3037.

Moore AG, Brown DA, Fairlie WD, Bauskin AR, Brown PK, Munier ML, Russell PK, Salamonsen LA, Wallace EM \& Breit SN 2000 The transforming growth factor-ss superfamily cytokine macrophage inhibitory cytokine- 1 is present in high concentrations in the serum of pregnant women. Journal of Clinical Endocrinology and Metabolism 85 4781-4788.
Morrish DW, Bhardwaj D \& Paras MT 1991 Transforming growth factor beta 1 inhibits placental differentiation and human chorionic gonadotropin and human placental lactogen secretion. Endocrinology $12922-26$.

Morrish DW, Dakour J \& Li H 2001 Life and death in the placenta: new peptides and genes regulating human syncytiotrophoblast and extravillous cytotrophoblast lineage formation and renewal. Current Protein and Peptide Science 2 245-259.

Moulton BC 1994 Transforming growth factor-beta stimulates endometrial stromal apoptosis in vitro. Endocrinology 134 1055-1060.

Mtango NR, Varisanga MD, Dong YJ, Rajamahendran R \& Suzuki T 2003 Growth factors and growth hormone enhance in vitro embryo production and post-thaw survival of vitrified bovine blastocysts. Theriogenology 59 1393-1402.

Munir S, Xu G, Wu Y, Yang B, Lala PK \& Peng C 2004 Nodal and ALK7 inhibit proliferation and induce apoptosis in human trophoblast cells. Journal of Biological Chemistry 279 31277-31286.

Munz B, Hubner G, Tretter Y, Alzheimer C \& Werner S 1999a A novel role of activin in inflammation and repair. Journal of Endocrinology 161 187-193.

Munz B, Smola H, Engelhardt F, Bleuel K, Brauchle M, Lein I, Evans LW, Huylebroeck D, Balling R \& Werner S 1999b Overexpression of activin $A$ in the skin of transgenic mice reveals new activities of activin in epidermal morphogenesis, dermal fibrosis and wound repair. EMBO Journal 18 5205-5215.

Murata M, Onomichi K, Eto Y, Shibai H \& Muramatsu M 1988 Expression of erythroid differentiation factor (EDF) in Chinese hamster ovary cells. Biochemical and Biophysical Research Communications 151 230-235.

Muttukrishna S, George L, Fowler PA, Groome NP \& Knight PG 1995 Measurement of serum concentrations of inhibin-A (alpha-beta $A$ dimer) during human pregnancy. Clinical Endocrinology (Oxford) 42 391-397.

Muttukrishna S, North RA, Morris J, Schellenberg JC, Taylor RS, Asselin J, Ledger W, Groome N \& Redman CW 2000 Serum inhibin $\mathrm{A}$ and activin A are elevated prior to the onset of pre-eclampsia. Human Reproduction 15 1640-1645.

Muttukrishna S, Bearfield C, Johns J \& Jauniaux E 2004 Inhibin, activin, follistatin, activin receptors and beta-glycan gene expression in the villous tissue of miscarriage patients. Molecular Human Reproduction 10 793-798.

Nagaeva O, Jonsson L \& Mincheva-Nilsson L 2002 Dominant IL-10 and TGF-beta mRNA expression in gammadeltaT cells of human early pregnancy decidua suggests immunoregulatory potential. American Journal of Reproductive Immunology 48 9-17.

Nasu K, Nishida M, Matsumoto H, Bing S, Inoue C, Kawano Y \& Miyakawa I 2005 Regulation of proliferation, motility, and contractivity of cultured human endometrial stromal cells by transforming growth factor-beta isoforms. Fertility and Sterility. 2 1114-1123.

Nowak RA, Haimovici F, Biggers JD \& Erbach GT 1999 Transforming growth factor-beta stimulates mouse blastocyst outgrowth through a mechanism involving parathyroid hormone-related protein. Biology of Reproduction 60 85-93.

O'Kane S \& Ferguson MW 1997 Transforming growth factor beta s and wound healing. International Journal of Biochemistry \& Cell Biology 29 63-78.

Ogawa K, Funaba M, Mathews LS \& Mizutani T 2000 Activin A stimulates type IV collagenase (matrix metalloproteinase-2) production in mouse peritoneal macrophages. Journal of Immunology 165 2997-3003.

Oh SP \& Li E 1997 The signaling pathway mediated by the type IIB activin receptor controls axial patterning and lateral asymmetry in the mouse. Genes \& Development 11 1812-1826.

Oh SP, Seki T, Goss KA, Imamura T, Yi Y, Donahoe PK, Li L, Miyazono K, ten Dijke P, Kim S, et al. 2000 Activin receptor-like kinase 1 modulates transforming growth factor-beta 1 signaling in the regulation of angiogenesis. PNAS 97 2626-2631. 
Orimo T, Taga M, Matsui H \& Minaguchi H 1996 The effect of activin-A on the development of mouse preimplantation embryos in vitro. Journal of Assisted Reproduction and Genetics 13 669-674.

Oshima M, Oshima H \& Taketo MM 1996 TGF-beta receptor type II deficiency results in defects of yolk sac hematopoiesis and vasculogenesis. Developmental Biology 179 297-302.

Osteen KG, Igarashi TM \& Bruner-Tran KL 2003 Progesterone action in the human endometrium: induction of a unique tissue environment which limits matrix metalloproteinase (MMP) expression. Frontiers in Bioscience 8 d78-d86.

Osterlund C \& Fried G 2000 TGFbeta receptor types I and II and the substrate proteins Smad 2 and 3 are present in human oocytes. Molecular Human Reproduction 6 498-503.

Otani T, Minami S, Kokawa K, Shikone T, Yamoto M \& Nakano R 1998 Immunohistochemical localization of activin A in human endometrial tissues during the menstrual cycle and in early pregnancy. Obstetrics and Gynecology 91 685-692.

Paria BC \& Dey SK 1990 Preimplantation embryo development in vitro: cooperative interactions among embryos and role of growth factors. PNAS 87 4756-4760.

Paria BC, Ma W, Tan J, Raja S, Das SK, Dey SK \& Hogan BL 2001 Cellular and molecular responses of the uterus to embryo implantation can be elicited by locally applied growth factors. PNAS 98 1047-1052.

Perrier d'Hauterive S, Charlet-Renard C, Dubois M, Berndt S, Goffin F, Foidart JM \& Geenen V 2005 Human endometrial leukemia inhibitory factor and interleukin-6: control of secretion by transforming growth factor-beta-related members. Neuroimmunomodulation 12 157-163.

Petraglia F, Vaughan J \& Vale W 1989 Inhibin and activin modulate the release of gonadotropin-releasing hormone, human chorionic gonadotropin, and progesterone from cultured human placental cells. PNAS 86 5114-5117.

Petraglia F, Florio P, Luisi S, Gallo R, Gadducci A, Vigano P, et al. 1998 Expression and secretion of inhibin and activin in normal and neoplastic uterine tissues. High levels of serum activin A in women with endometrial and cervical carcinoma. Journal of Clinical Endocrinology and Metabolism 83 1194-1200.

Pfendler KC, Yoon J, Taborn GU, Kuehn MR \& lannaccone PM 2000 Nodal and bone morphogenetic protein 5 interact in murine mesoderm formation and implantation. Genesis 28 1-14.

Pijnenborg R, Bland JM, Robertson WB \& Brosens I 1983 Uteroplacental arterial changes related to interstitial trophoblast migration in early human pregnancy. Placenta 4 397-413.

Polli V, Bulletti C, Galassi A, Borini A, Ciotti PM, Seracchioli R, Alfieri S \& Flamigni C 1996 Transforming growth factor-beta 1 in the human endometrium. Gynecological Endocrinology 10 297-302.

Prakash A, Laird S, Tuckerman E, Li TC \& Ledger WL 2005 Inhibin A and activin A may be used to predict pregnancy outcome in women with recurrent miscarriage. Fertility and Sterility $\mathbf{8 3}$ 1758-1763.

Proetzel G, Pawlowski SA, Wiles MV, Yin M, Boivin GP, Howles PN, Ding J, Ferguson MW \& Doetschman T 1995 Transforming growth factor-beta 3 is required for secondary palate fusion. Nature Genetics 11 409-414.

Qu J \& Thomas K 1995 Inhibin and activin production in human placenta. Endocrine Reviews 16 485-507.

Raghupathy R 2001 Pregnancy: success and failure within the Th1/Th2/Th3 paradigm. Seminars in Immunology 13 219-227.

Rankin CT, Bunton T, Lawler AM \& Lee SJ 2000 Regulation of left-right patterning in mice by growth/differentiation factor-1. Nature Genetics 24 262-265.

Rechtman MP, Zhang J \& Salamonsen LA 1999 Effect of inhibition of matrix metalloproteinases on endometrial decidualization and implantation in mated rats. Journal of Reproduction and Fertility 117 169-177.

Roberts HJ, Hu S, Qiu Q, Leung PC, Caniggia I, Gruslin A, Tsang B \& Peng C 2003 Identification of novel isoforms of activin receptor-like kinase 7 (ALK7) generated by alternative splicing and expression of ALK7 and its ligand, Nodal, in human placenta. Biology of Reproduction 68 1719-1726.

Robertson SA, Mau VJ, Hudson SN \& Tremellen KP 1997 Cytokineleukocyte networks and the establishment of pregnancy. American Journal of Reproductive Immunology 37 438-442.

Robertson SA, Ingman WV, O'Leary S, Sharkey DJ \& Tremellen KP 2002 Transforming growth factor beta-a mediator of immune deviation in seminal plasma. Journal of Reproductive Immunology 57 109-128.

Roelen BA, Goumans MJ, Zwijsen A \& Mummery CL 1998 Identification of two distinct functions for TGF-beta in early mouse development. Differentiation 64 19-31.

Rook AH, Kehrl JH, Wakefield LM, Roberts AB, Sporn MB, Burlington DB, Lane HC \& Fauci AS 1986 Effects of transforming growth factor beta on the functions of natural killer cells: depressed cytolytic activity and blunting of interferon responsiveness. Journal of Immunology 136 3916-3920.

Roopa BA, Loganath A \& Singh K 2003 The effect of a levonorgestrelreleasing intrauterine system on angiogenic growth factors in the endometrium. Human Reproduction 18 1809-1819.

Saito S, Morii T, Enomoto M, Sakakura S, Nishikawa K, Narita N \& Ichijo M 1993 The effect of interleukin 2 and transforming growth factor-beta 2 (TGF-beta 2) on the proliferation and natural killer activity of decidual CD16- CD56bright natural killer cells. Cellular Immunology 152 605-613.

Salamonsen LA \& Lathbury LJ 2000 Endometrial leukocytes and menstruation. Human Reproduction Update 6 16-27.

Salamonsen LA \& Jones RL 2003 Endometrial remodeling. In Encylopedia of Hormones, pp 504-512. Ed. J M. San Diego, USA: Academic Press.

Samuels P \& Tan AK 1999 Fetal scarless wound healing. Journal of Otolaryngology 28 296-302.

Sanford LP, Ormsby I, Gittenberger-de Groot AC, Sariola H, Friedman R, Boivin GP, Cardell EL \& Doetschman T 1997 TGFbeta2 knockout mice have multiple developmental defects that are non-overlapping with other TGFbeta knockout phenotypes. Development 124 2659-2670.

Schilling B \& Yeh J 2000 Transforming growth factor-beta(1), -beta(2), beta(3) and their type I and II receptors in human term placenta. Gynecologic and Obstetric Investigation 50 19-23.

Schmidt-Weber CB \& Blaser K 2004 Regulation and role of transforming growth factor-beta in immune tolerance induction and inflammation. Current Opinion in Immunology 16 709-716.

Selick CE, Horowitz GM, Gratch M, Scott RT Jr, Navot D \& Hofmann GE 1994 Immunohistochemical localization of transforming growth factor-beta in human implantation sites. Journal of Clinical Endocrinology and Metabolism 78 592-596.

Settle S, Marker P, Gurley K, Sinha A, Thacker A, Wang Y, Higgins K, Cunha G \& Kingsley DM 2001 The BMP family member Gdf7 is required for seminal vesicle growth, branching morphogenesis, and cytodifferentiation. Developmental Biology 234 138-150.

Shah M, Foreman DM \& Ferguson MW 1994 Neutralising antibody to TGF-beta 1,2 reduces cutaneous scarring in adult rodents. Journal of Cell Science 107 1137-1157.

Shooner C, Caron PL, Frechette-Frigon G, Leblanc V, Dery MC \& Asselin E 2005 TGF-beta expression during rat pregnancy and activity on decidual cell survival. Reproductive Biology and Endocrinology 320.

Shull MM, Ormsby I, Kier AB, Pawlowski S, Diebold RJ, Yin M, Allen R, Sidman C, Proetzel G, Calvin D, et al. 1992 Targeted disruption of the mouse transforming growth factor-beta 1 gene results in multifocal inflammatory disease. Nature 359 693-699.

Simpson H, Robson SC, Bulmer JN, Barber A \& Lyall F 2002 Transforming growth factor beta expression in human placenta and placental bed during early pregnancy. Placenta 23 44-58. 
Solloway MJ \& Robertson EJ 1999 Early embryonic lethality in Bmp5;Bmp7 double mutant mice suggests functional redundancy within the 60A subgroup. Development 126 1753-1768.

Solloway MJ, Dudley AT, Bikoff EK, Lyons KM, Hogan BL \& Robertson EJ 1998 Mice lacking Bmp6 function. Developmental Genetics 22 321-339.

Song Y, Keelan J \& France JT 1996 Activin-A stimulates, while transforming growth factor beta 1 inhibits, chorionic gonadotrophin production and aromatase activity in cultured human placental trophoblasts. Placenta 17 603-610.

Song J, Oh SP, Schrewe H, Nomura M, Lei H, Okano M, Gridley T \& Li E 1999 The type II activin receptors are essential for egg cylinder growth, gastrulation, and rostral head development in mice. Developmental Biology 213 157-169.

Spencer K, Yu CK, Savvidou M, Papageorghiou AT \& Nicolaides KH 2006 Prediction of pre-eclampsia by uterine artery Doppler ultrasonography and maternal serum pregnancy-associated plasma protein- $\mathrm{A}$, free beta-human chorionic gonadotropin, activin $\mathrm{A}$ and inhibin $\mathrm{A}$ at $22+0$ to $24+6$ weeks' gestation. Ultrasound in Obstetrics and Gynecology 27 658-663.

Stenvers KL, Tursky ML, Harder KW, Kountouri N, AmatayakulChantler S, Grail D, Small C, Weinberg RA, Sizeland AM \& Zhu HJ 2003 Heart and liver defects and reduced transforming growth factor beta2 sensitivity in transforming growth factor beta type III receptor-deficient embryos. Molecular and Cellular Biology 23 4371-4385.

St-Jacques S, Forte M, Lye SJ \& Letarte M 1994 Localization of endoglin, a transforming growth factor-beta binding protein, and of CD44 and integrins in placenta during the first trimester of pregnancy. Biology of Reproduction 51 405-413.

Storm EE, Huynh TV, Copeland NG, Jenkins NA, Kingsley DM \& Lee SJ 1994 Limb alterations in brachypodism mice due to mutations in a new member of the TGF beta-superfamily. Nature 368 639-643.

Strakova Z, Szmidt M, Srisuparp S \& Fazleabas AT 2003 Inhibition of matrix metalloproteinases prevents the synthesis of insulin-like growth factor binding protein-1 during decidualization in the baboon. Endocrinology 144 5339-5346.

Tabibzadeh S 2002 Decoding implantation and menstruation: the tale of two opposing signals. Frontiers in Bioscience 7 1475-1486.

Tang M, Taylor HS \& Tabibzadeh S 2005a In vivo gene transfer of lefty leads to implantation failure in mice. Human Reproduction $\mathbf{2 0}$ 1772-1778.

Tang M, Xu Y, Julian J, Carson D \& Tabibzadeh S 2005b Lefty is expressed in mouse endometrium in estrous cycle and periimplantation period. Human Reproduction 20 872-880.

Tessier C, Prigent-Tessier A, Bao L, Telleria CM, Ferguson-Gottschall S, Gibori GB, Gu Y, Bowen-Shauver JM, Horseman ND \& Gibori G 2003 Decidual activin: its role in the apoptotic process and its regulation by prolactin. Biology of Reproduction 68 1687-1694.

Tierney EP \& Giudice LC 2004 Role of activin A as a mediator of in vitro endometrial stromal cell decidualization via the cyclic adenosine monophosphate pathway. Fertility and Sterility 81 (Supplement 1) 899-903.

Tong S, Marjono B, Brown DA, Mulvey S, Breit SN, Manuelpillai U \& Wallace EM 2004 Serum concentrations of macrophage inhibitory cytokine 1 (MIC 1 ) as a predictor of miscarriage. Lancet 363 129-130.

Tremblay KD, Dunn NR \& Robertson EJ 2001 Mouse embryos lacking Smad1 signals display defects in extra-embryonic tissues and germ cell formation. Development 128 3609-3621.

Tse WK, Whitley GS \& Cartwright JE 2002 Transforming growth factorbeta1 regulates hepatocyte growth factor-induced trophoblast motility and invasion. Placenta 23 699-705.

Vassalli A, Matzuk MM, Gardner HA, Lee KF \& Jaenisch R 1994 Activin/inhibin beta B subunit gene disruption leads to defects in eyelid development and female reproduction. Genes \& Development 8 414-427.
Verma S, Hiby SE, Loke YW \& King A 2000 Human decidual natural killer cells express the receptor for and respond to the cytokine interleukin 15. Biology of Reproduction 62 959-968.

Wallace EM, Swanston IA, McNeilly AS, Ashby JP, Blundell G, Calder AA \& Groome NP 1996 Second trimester screening for Down's syndrome using maternal serum dimeric inhibin A. Clinical Endocrinology 44 17-21.

Wallace EM, Schneider-Kolsky ME, Edwards A, Baker L \& Jenkin G 2003 Maternal serum activin A levels in association with intrauterine fetal growth restriction. BJOG 110 306-310.

Wallace EM, Marjono B, Tyzack K \& Tong S 2004 First trimester levels of inhibins and activin A in normal and failing pregnancies. Clinical Endocrinology 60 484-490.

Wankell M, Munz B, Hubner G, Hans W, Wolf E, Goppelt A \& Werner S 2001 Impaired wound healing in transgenic mice overexpressing the activin antagonist follistatin in the epidermis. EMBO Journal 20 5361-5372.

Weinstein M, Yang X, Li C, Xu X, Gotay J \& Deng CX 1998 Failure of egg cylinder elongation and mesoderm induction in mouse embryos lacking the tumor suppressor smad2. PNAS 95 9378-9383.

Winnier G, Blessing M, Labosky PA \& Hogan BL 1995 Bone morphogenetic protein-4 is required for mesoderm formation and patterning in the mouse. Genes \& Development 9 2105-2116.

Woodruff TK, Sluss P, Wang E, Janssen I \& Mersol-Barg MS 1997 Activin $\mathrm{A}$ and follistatin are dynamically regulated during human pregnancy. Journal of Endocrinology 152 167-174.

Xu RH 2006 In vitro induction of trophoblast from human embryonic stem cells. Methods in Molecular Medicine 121 189-202.

Xu G, Guimond MJ, Chakraborty C \& Lala PK 2002 Control of proliferation, migration, and invasiveness of human extravillous trophoblast by decorin, a decidual product. Biology of Reproduction 67 681-689.

Xu G, Chakraborty C \& Lala PK 2003 Reconstitution of Smad3 restores TGF-beta response of tissue inhibitor of metalloprotease-1 upregulation in human choriocarcinoma cells. Biochemical and Biophysical Research Communications 300 383-390.

Yan C, Wang P, DeMayo J, DeMayo FJ, Elvin JA, Carino C, Prasad SV, Skinner SS, Dunbar BS, Dube JL, et al. 2001 Synergistic roles of bone morphogenetic protein 15 and growth differentiation factor 9 in ovarian function. Molecular Endocrinology 15 854-866.

Yang X, Li C, Xu X \& Deng C 1998 The tumor suppressor SMAD4/DPC4 is essential for epiblast proliferation and mesoderm induction in mice. PNAS 95 3667-3672.

Yi SE, LaPolt PS, Yoon BS, Chen JY, Lu JK \& Lyons KM 2001 The type I $\mathrm{BMP}$ receptor BmprlB is essential for female reproductive function. PNAS 98 7994-7999.

Ying Y \& Zhao GQ 2000 Detection of multiple bone morphogenetic protein messenger ribonucleic acids and their signal transducer, Smad1, during mouse decidualization. Biology of Reproduction 63 1781-1786.

Ying Y, Liu XM, Marble A, Lawson KA \& Zhao GQ 2000 Requirement of Bmp8b for the generation of primordial germ cells in the mouse. Molecular Endocrinology 14 1053-1063.

Yoshioka K, Suzuki C \& Iwamura S 1998 Activin A and follistatin regulate developmental competence of in vitro-produced bovine embryos. Biology of Reproduction 59 1017-1022.

Yu J \& Dolter KE 1997 Production of activin A and its roles in inflammation and hematopoiesis. Cytokines, Cellular \& Molecular Therapy 3 169-177.

Zhang H \& Bradley A 1996 Mice deficient for BMP2 are nonviable and have defects in amnion/chorion and cardiac development. Development 122 2977-2986.

Zhao Y, Chegini N \& Flanders KC 1994 Human fallopian tube expresses transforming growth factor (TGF beta) isoforms, TGF beta type I-III receptor messenger ribonucleic acid and protein, and contains [125I]TGF beta-binding sites. Journal of Clinical Endocrinology and Metabolism 79 1177-1184. 
Zhao GQ, Liaw L \& Hogan BL 1998 Bone morphogenetic protein 8A plays a role in the maintenance of spermatogenesis and the integrity of the epididymis. Development 125 1103-1112.

Zhao R, Lawler AM \& Lee S-J 1999 Characterization of GDF-10 expression patterns and null mice. Developmental Biology 21268.

Zhou Y, Fisher SJ, Janatpour M, Genbacev O, Dejana E, Wheelock M \& Damsky CH 1997 Human cytotrophoblasts adopt a vascular phenotype as they differentiate, A strategy for successful endovascular invasion? Journal of Clinical Investigation 99 2139-2151.

Zhu Y, Richardson JA, Parada LF \& Graff JM 1998 Smad3 mutant mice develop metastatic colorectal cancer. Cell 94 703-714.

Zipori D \& Barda-Saad M 2001 Role of activin A in negative regulation of normal and tumor B lymphocytes. Journal of Leukocyte Biology $69867-873$.
Zwijsen A, Goumans MJ, Lawson KA, Van Rooijen MA \& Mummery CL 1999 Ectopic expression of the transforming growth factor beta type II receptor disrupts mesoderm organisation during mouse gastrulation. Developmental Dynamics 214 141-151.

Zwijsen A, van Rooijen MA, Goumans MJ, Dewulf N, Bosman EA, ten Dijke P, Mummery CL \& Huylebroeck D 2000 Expression of the inhibitory Smad7 in early mouse development and upregulation during embryonic vasculogenesis. Developmental Dynamics 218 663-670.

Received 8 February 2006

First decision 7 April 2006

Revised manuscript received 3 May 2006

Accepted 18 May 2006 